\title{
Thymocyte Selection-Associated High Mobility Group Box Protein TOX
}

National Cancer Institute

\section{Source}

National Cancer Institute. Thymocyte Selection-Associated High Mobility Group Box

Protein TOX. NCI Thesaurus. Code C147950.

Thymocyte selection-associated high mobility group box protein T OX (526 aa, 58 kDa)

is encoded by the human TOX gene. This protein plays a role in thymocyte development. 